\title{
THE MYCOLOGICAL STATUS OF GREEN FORAGES AND SILAGES FROM A MIXTURE OF LEGUMES WITH GRASSES AND WHOLE CROP MAIZE
}

\author{
STATUS MIKOLOGICZNY ZIELONEK I KISZONEK Z MIESZANKI ROŚLIN \\ BOBOWATYCH Z TRAWAMI ORAZ Z CAŁYCH ROŚLIN KUKURYDZY
}

\author{
Department of Animal Science, UTP University of Science and Technology, Bydgoszcz, Poland
}

\begin{abstract}
Streszczenie. Liczba grzybów (drożdży i pleśni) w kiszonkach jest wyznacznikiem ich jakości higienicznej. Materiałem badawczym były zielonki z mieszanki roślin bobowatych z trawami oraz z całych roślin kukurydzy. Badania prowadzono w latach 2012-2014. Co roku zakiszano zielonkę z 2 pokosu mieszanki bobowato-trawiastej z 3-letniej uprawy polowej. Natomiast zielonkę z kukurydzy tej samej odmiany, uprawianej zgodnie z zasadami zmianowania, zakiszano po osiągnięciu przez rośliny dojrzałości woskowej. Rozdrobnione zielonki ugnieciono i zakiszono w zbiornikach doświadczalnych o pojemności $8654 \mathrm{~cm}^{3}$, które otwarto po 6 tygodniach. W celu ustalenia liczebności pleśni i drożdży w zielonkach i kiszonkach wykonano analizę mikologiczną zgodnie z PN-ISO 21527-1 : 2009. Status mikologiczny zakiszanych zielonek był zły. Liczebność pleśni w zielonkach $z$ mieszanki bobowato-trawiastej wynosiła od 5,4225 (w 3 roku) do $5,4472 \mathrm{lg}$ jtk $\cdot \mathrm{g}^{-1}$ (w 1 roku), natomiast drożdży było od 4,9977 (w 3 roku) do 5,5792 lg jtk $\cdot \mathrm{g}^{-1}$ (w 1 roku). Pleśnie $w$ zielonkach z całych roślin kukurydzy występowały w liczbie od 4,6514 (w 1 roku) do 6,4928 lg jtk $\cdot \mathrm{g}^{-1}$ (w 2 roku), natomiast drożdże - w liczbie od 6,6710 (w 2 roku) do $7,2657 \mathrm{lg}$ jtk $\cdot \mathrm{g}^{-1}$ ( $\mathrm{w} 1$ roku). W kiszonkach odnotowano istotnie $(P \leq 0,001)$ mniej grzybów niż w zielonkach. Jakość higieniczna kiszonek z mieszanki bobowato-trawiastej była dobra w każdym roku badań. Liczebność pleśni i drożdży nie przekroczyła $3 \mathrm{lg}$ jtk $\cdot \mathrm{g}^{-1}$. Kiszonki z całych roślin kukurydzy cechowały się złą jakością higieniczną. Jedynie w kiszonce z 3 roku badań odnotowano występowanie pleśni na poziomie 1,7940 , ale drożdży było $6,2810 \mathrm{lg}$ jtk $\cdot \mathrm{g}^{-1}$.
\end{abstract}

Key words: fungi, grass, hygienic quality, legumes, maize, mould, yeast.

Słowa kluczowe: bobowate, drożdże, grzyby, jakość higieniczna, kukurydza, pleśnie, trawa.

\section{INTRODUCTION}

Forage are evaluated for their suitability for feeding on the basis of their nutritional value. An important criterion of evaluation is also their hygienic quality, which is indicated by the presence of fungi - mould and yeast (Wagner et al. 2007; Wiedner 2009; Muck 2010, Kukier et al. 2012). For forage, there are no reference values for the number of these microorganisms (Wagner et al. 2007). In the Regulation (EC) No. 183/2005 of the European Parliament and of the Council of 12 January 2005 laying down requirements for feed hygiene, no indicators were provided for the number of moulds and yeasts in forages.

Corresponding author - Adres do korespondencji: Piotr Dorszewski, Department of Animal Science, UTP University of Science and Technology, Bydgoszcz, Mazowiecka 28, 85-084 Bydgoszcz, Poland, e-mail: piodor@utp.edu.pl 
Research results indicate that the presence of fungi in forages is high (Bauer 2004; Grajewski et al. 2007; Potkański et al. 2010). Ensiling improves the mycological status of biomass, as the number of moulds and yeasts in silage is less than in green forages. During the lactic fermentation, almost all fungal spores die (Lin et al. 1995; Grajewski et al. 2004; Bauer and Mayer 2006).

The aim of the study was to determine the mycological status (moulds and yeasts number) of green forages and silages from a mixture of legumes with grasses as well as of whole maize crop over the years 2012-2014.

\section{MATERIAL AND METHODS}

The research material consisted of green forages of a mixture of legumes with grasses and whole crop maize and silages were made from them. The research was conducted in the

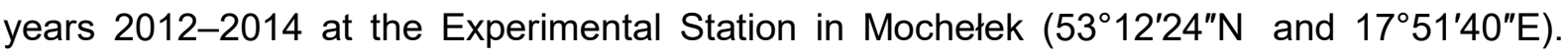
A mixture of legumes with grasses (the proportion of alfalfa seeds and red clover to the timothy seeds and red fescue $-4.6: 1$ ) intended for 3 years of use was sown on arable land. Maize of the med-late hybrid (FAO 280) was cultivated according to the rules of crop rotation. Biomass of the second swath of legume-grasses mixture was chopped with a forage harvester in the alfalfa initial blooming phase, and before earning of grasses (harvest time -2 nd half of July, weather conditions: average temperature - 18.8 (1st year), 18.9 (2nd year), $21.5^{\circ} \mathrm{C}$ (3rd year), average rainfall - 87.7 (1st year), 79.0 (2nd year), $55.4 \mathrm{~mm}$ (3rd year). The whole crop maize was harvested in the wax stage with a forage harvester with a grain crusher (harvest time 2nd half of September, weather conditions: average temperature - 13.3 (1st year), 10.7 (2nd year) $14.4^{\circ} \mathrm{C}$ (3rd year), average rainfall - 25.1 (1st year), 64.1 (2nd year), $14.4 \mathrm{~mm}$ (3rd year). The green forage was chopped to chaff with medium theoretical length amounting to $1.5 \mathrm{~cm}$. From each of the tested green forages, 12 samples were taken for dry matter analysis and for mycological tests. Silages were prepared every year in 24 minisilos of PVC with a capacity of $8654 \mathrm{~cm}^{3}$ each (diameter $15 \mathrm{~cm}$, height $49 \mathrm{~cm}$ ) without silage additives (12 silos for each green forage). Biomass was compacted using a special hydraulic device (press) with constant pressure $6 \cdot 10^{5} \mathrm{~N} \cdot \mathrm{m}^{-2}$ during pressing. The minisilos were sealed with rubber stoppers equipped with fermentation tubes filled with glycerine that allowed the channelling of fermentation gasses and they were stored in an air-conditioned room at a temperature of $20 \pm 1^{\circ} \mathrm{C}$. The silage was removed 6 weeks after the date of ensiling. Biomass was spilled from each minisilos, mixed and sampled for chemical analyses and mycological tests.

The basic parameters of ensiled green forages and silages obtained are given in Table 1.

The samples were prepared for analysis according to PN-EN ISO 6887-1 : 2000. Dry matter content in green fodders and silages was determined by the drying method and in silage $-\mathrm{pH}$ using the phmeter N-5172 and lactic, acetic and butyric acid content (AOAC 2012). The number of moulds and yeasts was determined according to PN-ISO 21527-1 : 2009. The mycological study was performed on YGC agar medium (yeast extract, $100 \mathrm{ppm}$ chloramphenicol glucose), incubating the samples at a temperature of $25 \pm 1^{\circ} \mathrm{C}$ for $5-7$ days. The count was expressed as the $\lg$ of number of colony forming units ( $\operatorname{lg~cfu}$ ) in a $1 \mathrm{~g}$ of sample. 
Table 1. Parameters of green forages and silages

Tabela 1. Parametry zielonek i kiszonek

\begin{tabular}{|c|c|c|c|c|c|c|}
\hline \multirow{3}{*}{$\begin{array}{c}\text { Item } \\
\text { Wyszczególnienie }\end{array}$} & \multirow{3}{*}{$\begin{array}{l}\text { DM } \\
{\left[\mathrm{g} \cdot \mathrm{kg}^{-1}\right.} \\
\text { of green } \\
\text { forage - } \\
\text { zielonki] }\end{array}$} & \multirow{3}{*}{$\begin{array}{c}\mathrm{DM} \\
{\left[\mathrm{g} \cdot \mathrm{kg}^{-1}\right.} \\
\text { of silage - } \\
\text { kiszonki] }\end{array}$} & \multirow{3}{*}{$\mathrm{pH}$} & \multicolumn{3}{|c|}{ Acids - Kwasy } \\
\hline & & & & $\begin{array}{l}\text { lactic } \\
\text { mlekowy }\end{array}$ & $\begin{array}{l}\text { acetic } \\
\text { octowy }\end{array}$ & $\begin{array}{l}\text { butyric } \\
\text { masłowy }\end{array}$ \\
\hline & & & & \multicolumn{3}{|c|}{$\left[\mathrm{g} \cdot \mathrm{kg}^{-1} \mathrm{DM}\right.$ of silage - kiszonki] } \\
\hline \multicolumn{7}{|c|}{ Mixture of legumes and grasses - Mieszanka roślin bobowatych z trawami } \\
\hline \multirow[t]{2}{*}{ 1st year -1 rok } & 25.33 & 23.22 & 4.86 & 74.08 & 45.46 & 0.41 \\
\hline & \pm 0.31 & \pm 0.04 & \pm 0.10 & \pm 0.98 & \pm 0.73 & \pm 0.06 \\
\hline \multirow[t]{2}{*}{ 2nd year - 2 rok } & 23.06 & 22.71 & 4.98 & 74.19 & 41.70 & 1.72 \\
\hline & \pm 0.26 & \pm 0.12 & \pm 0.04 & \pm 1.96 & \pm 1.78 & \pm 0.35 \\
\hline \multirow[t]{2}{*}{3 rd year -3 rok } & 22.75 & 24.65 & 4.69 & 99.87 & 25.81 & 1.66 \\
\hline & \pm 0.04 & \pm 0.40 & \pm 0.30 & \pm 1.88 & \pm 1.36 & \pm 0.14 \\
\hline \multicolumn{7}{|c|}{ Whole crop maize - Całe rośliny kukurydzy } \\
\hline \multirow[t]{2}{*}{ 1st year -1 rok } & 32.68 & 32.27 & 4.11 & 70.52 & 16.24 & nd. \\
\hline & \pm 0.77 & \pm 0.90 & \pm 0.02 & \pm 1.55 & \pm 0.99 & \\
\hline \multirow[t]{2}{*}{2 nd year -2 rok } & 32.05 & 32.57 & 4.14 & 85.5 & 26.88 & nd. \\
\hline & \pm 0.79 & \pm 0.29 & \pm 0.04 & \pm 1.45 & \pm 1.12 & \\
\hline \multirow[t]{2}{*}{3 rd year -3 rok } & 32.86 & 34.64 & 4.35 & 87.10 & 14.83 & nd. \\
\hline & \pm 1.01 & \pm 0.11 & \pm 0.08 & \pm 1.23 & \pm 1.11 & \\
\hline
\end{tabular}

DM - dry matter - sucha masa, nd. - not detected - nie wykryto.

Results were statistically calculated using the Statistica programme. The significance of differences between means was verified by a t-Student test.

\section{RESULTS AND DISCUSSION}

The degree of moulds contamination of green forages from the legume-grasses mixture exceeded the value of $5.4 \mathrm{lg} \mathrm{cfu} \cdot \mathrm{g}^{-1}$ (Fig. 1). Analysis of the quantity of these microorganisms after the opening of silage minisilos showed a significant $(P \leq 0.001)$ over 2 times decrease in their population.

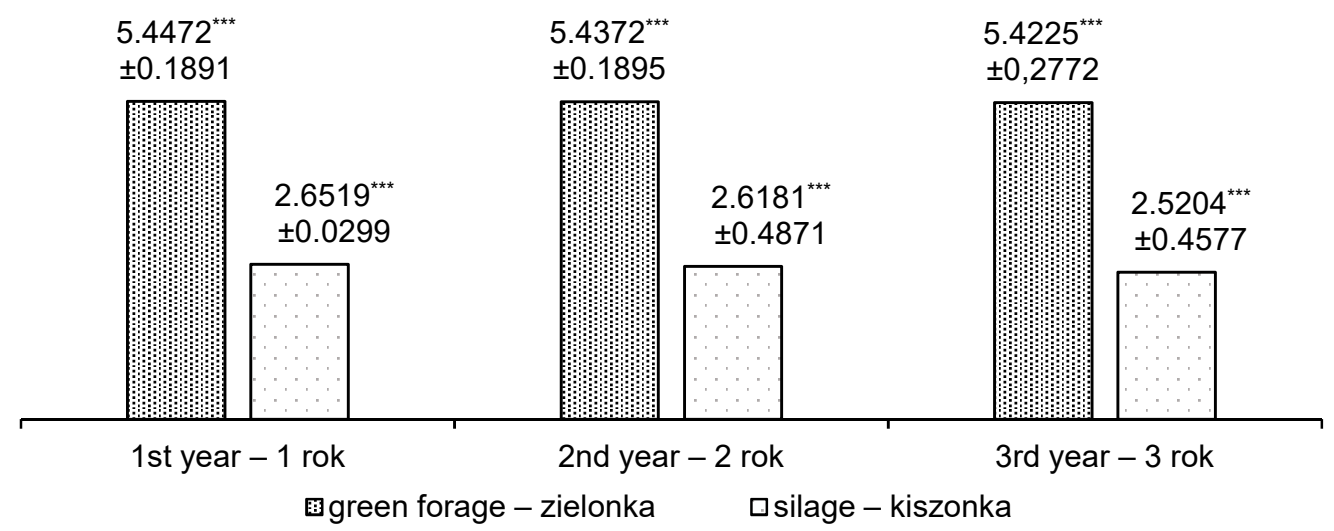

Fig. 1. Number of moulds on green forages and in silages from legume-grasses mixture $\left[\mathrm{lg} \mathrm{cfu} \cdot \mathrm{g}^{-1}\right.$ fresh matter]; ${ }^{* *} P \leq 0.001$

Ryc. 1. Liczebność pleśni na zielonkach i w kiszonkach z mieszanki roślin bobowatych $z$ trawami [log jtk $\cdot \mathrm{g}^{-1}$ świeżej masy]; ${ }^{* \star} \mathrm{P} \leq 0,001$ 
The number of yeasts in the 1 st and 2 nd year exceeded 5.5 and in the 3 rd year it was almost $5 \mathrm{lg} \mathrm{cfu} \cdot \mathrm{g}^{-1}$ (Fig. 2) In silage, there was significantly less of these microorganisms $(P \leq 0.001)$. There was a 3-4.5 times decrease in their number compared to green forages.

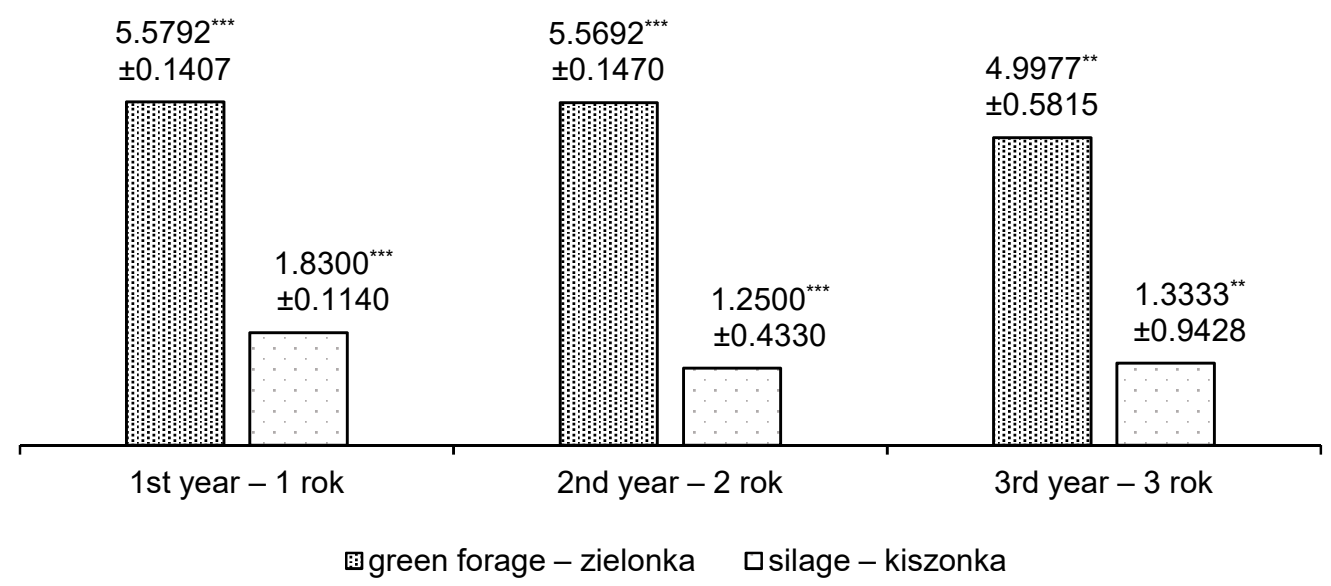

Fig. 2. Number of yeasts on green forages and in silages from legume-grasses mixture $\left[\mathrm{lg} \mathrm{cfu} \cdot \mathrm{g}^{-1}\right.$ fresh matter]; ${ }^{* *} \mathrm{P} \leq 0.001$

Ryc. 2. Liczebność drożdży na zielonkach i w kiszonkach z mieszanki roślin bobowatych z trawami [log jtk $\cdot \mathrm{g}^{-1}$ świeżej masy]; ${ }^{* * *} \mathrm{P} \leq 0,001$

The presence of moulds on the green fodders from whole crop maize exceeded the value of $4.6 \mathrm{lg} \mathrm{cfu} \cdot \mathrm{g}^{-1}$ (Fig. 3). After the fermentation, their quantity decreased significantly $(P \leq 0.001)$ for the 1 st and 2 nd year of the study. In the 3rd year, only a not significantly decrease in their numbers was recorded $2.48 \%$.

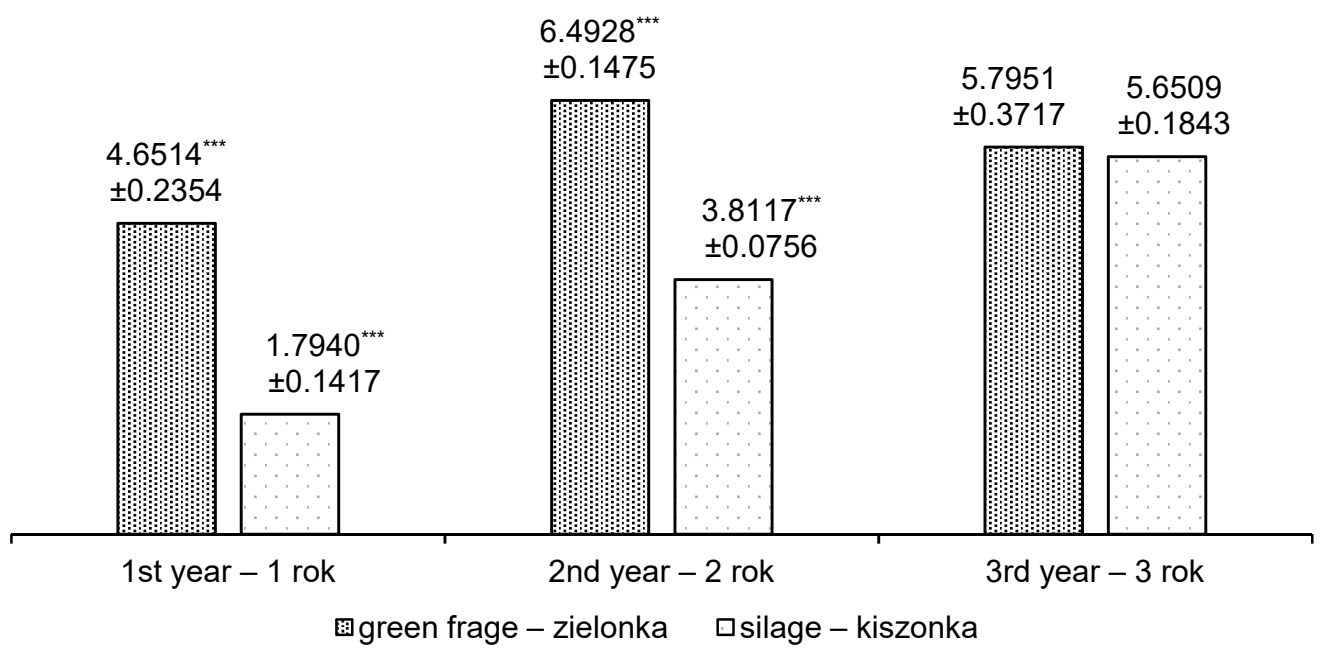

Fig. 3. Number of moulds on green forages and in silages from whole crop maize [lg cfu $\cdot \mathrm{g}^{-1}$ fresh matter]; ${ }^{* * *} \mathrm{P} \leq 0.001$

Ryc. 3. Liczebność pleśni na zielonkach i w kiszonkach z całych roślin kukurydzy [log jtk $\cdot \mathrm{g}^{-1}$ świeżej masy]; ${ }^{* * *} \mathrm{P} \leq 0,001$

The number of yeast exceeds the value of $6.6 \mathrm{lg} \mathrm{cfu} \cdot \mathrm{g}^{-1}$ of maize green forages (Fig. 4). In silages, their quantity was significant $(P \leq 0.001)$ lower by over $12.5 \%$ in the $3 r d$ year, above $13.5 \%$ in the 1 st year and above $14.7 \%$ in the 2 nd year of research. 


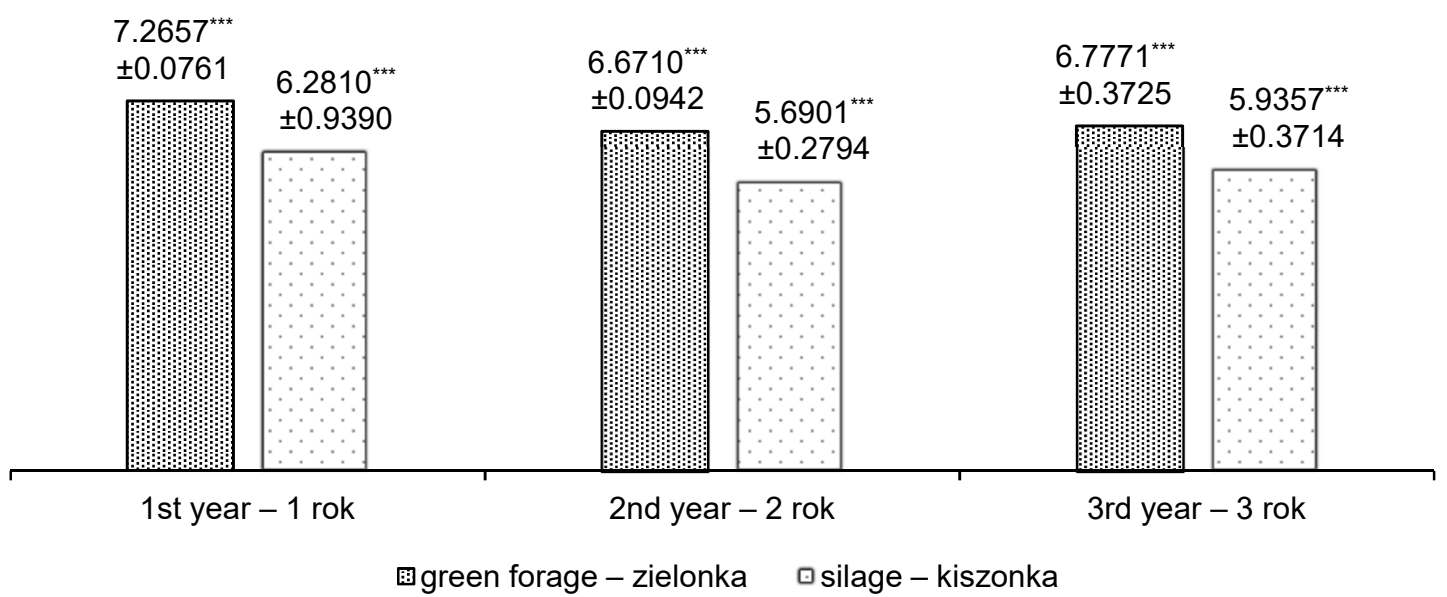

Fig. 4. Number of yeasts on green forages and in silages from whole crop maize $\left[\mathrm{lg} \mathrm{cfu} \cdot \mathrm{g}^{-1}\right.$ fresh matter]; ${ }^{* *} \mathrm{P} \leq 0.001$

Ryc. 4. Liczebność drożdży na zielonkach i w kiszonkach z całych roślin kukurydzy [log jtk $\cdot \mathrm{g}^{-1}$ świeżej masy]; ${ }^{* * *} \mathrm{P} \leq 0,001$

According to literature, the number of moulds on the plants is from 3 to $4 \mathrm{lg} \mathrm{cfu} \cdot \mathrm{g}^{-1}$, and yeast - from 3 to $5 \mathrm{lg} \mathrm{cfu} \cdot \mathrm{g}^{-1}$ (Bauer 2004; Pahlow et al. 2003). In raw materials of good hygienic quality the number of fungi should not exceed $4 \mathrm{lg} \mathrm{cfu} \cdot \mathrm{g}^{-1}$ (Alonso et al. 2013). Comparing fungal numbers in our own studies with data from literature shows that the ensilaged green forages had bad hygienic quality.

In the silage, the quantity of mould can reach $3.6990 \mathrm{lg} \mathrm{cfu} \cdot \mathrm{g}^{-1}$ (Wagner et al. 2007). Our own data indicate that the presence of mould in legume-grasses silages was from 28.31 to $31.86 \%$ lower than in literature (Wagner et al. 2007). Wiedner (2009) informs that in good grass silage the number of mould and yeast should not exceed $4 \mathrm{lg} \mathrm{cfu} \cdot \mathrm{g}^{-1}$ and if it amounts to $5 \mathrm{lg} \mathrm{cfu} \cdot \mathrm{g}^{-1}$, silages have bad hygienic quality. Despite the considerable number of moulds and yeasts in the green forages in an own study, their level in silage was significantly lower than that reported in literature (Wiedner 2009).

According to Wagner et al. (2007) in good silage from maize, the number of mould should not exceed $4 \mathrm{lg} \mathrm{cfu} \cdot \mathrm{g}^{-1}$, and the bad ones have over $5 \mathrm{lg} \mathrm{cfu} \cdot \mathrm{g}^{-1}$. The results of our own research indicate that in whole maize silages the values reported in literature were exceeded in the 3rd year of research.

In silage, the quantity of yeast can reach a level of $6 \mathrm{lg} \mathrm{cfu} \cdot \mathrm{g}^{-1}$ (Wagner et al. 2007). This value is from 69.5 to $79.2 \%$ higher than in legume-grasses silages in our research. In good maize silage, the number of yeast should not exceed $4 \mathrm{lg} \mathrm{cfu} \cdot \mathrm{g}^{-1}$ (Wagner et al. 2007). In own studies, their populations in silages from whole crop maize were higher from 1.6901 (2nd year) to 2.2810 ( 1 st year) $\operatorname{lg~cfu} \cdot \mathrm{g}^{-1}$, but did not exceed the value of $7 \mathrm{lg} \mathrm{cfu} \cdot \mathrm{g}^{-1}$, which characterizes bad silage from these plants (Wagner et al. 2007).

High hygienic qualities are shown by grass or maize silage, in which the number of moulds and yeast does not exceed $3 \mathrm{lg} \mathrm{cfu} \cdot \mathrm{g}^{-1}$ (Wagner et al. 2007). In own studies, this indicator was not exceeded only in silage from a mixture of legumes and grasses, which indicates that they had high hygienic quality. In maize silages, the number of moulds was in a range from 
0.8117 (2nd year) to $2.6509 \mathrm{cfu} \cdot \mathrm{g}^{-1}$ (3rd year) greater than published in literature. Only in the 1 st year of our research, the number of these microorganisms in silage was $59.8 \%$ lower than the value indicated by Wagner et al. (2007), while the yeast number was 2 times higher.

\section{CONCLUSIONS}

In green forges from a mixture of legumes and grasses as well as whole crop maize, a large number of moulds and yeasts were found, which indicates their bad hygienic quality. In silage, the number of these microorganisms was noted as considerably lower. The fermentation process has limited their occurrence. The hygienic quality of silages from the legume-grasses mixture was good in each year of the study. Silages from whole crop maize, despite a decrease in the number of fungi compared to green fodder, had bad hygienic quality.

\section{REFERENCES}

Alonso V.A., Pereyra C.M., Keller L.A.M., Dalcero A.M., Rosa C.A.R., Chiacchiera S.M., Cavaglieri L.R. 2013. Fungi and mycotoxins in silage: An overview. J. Appl. Microbiol. 115, 637-643. DOI:10.1111/jam.12178.

AOAC. 2012. Official methods of analysis. 19th ed. Gaithersburg, USA, Association of Official Analytical Chemists.

Bauer J. 2004. Mikrobiologie der Silierung. 20. Hülsenberger Gespräche Mikrobiologe und Tierernährung. Lübeck, Aus der Schriftenreihe der H. Wilhelm Schaumann Stiftung, 65-72.

Bauer J., Meyer K. 2006. Stoffwechselprodukte von Pilzen in Silagen: Einflüsse auf die Gesundheit von Nutztieren. Tierernährg, Übers. 34, 27-55.

Grabowska M., Gubała A., Selwet M. 2007. Hygienic quality of corn silage with a biological and chemical additive. Med. Weter. 63, 205-208.

Grajewski J., Potkański A., Raczkowska-Werwińska K., Twarużek M., Miklaszewska B., Kukier E., Goldsztejn M., Grenda T., Kwiatek K., Wasyl D., Hoszowski A. 2012. Microbial quality of compound feed used in Poland. Bull. Vet. Inst. Pulawy 56, 349-354.

Lin C., Bolsen K.K., Brent B.E., Hart R.A., Dickerson J.T., Feyerherm A.M., Aimutis W.R. 1995. Epiphytic microflora on alfalfa and whole-plant corn. J. Dairy Sci. 75, 2484-2493.

Muck R.E. 2010. Silage microbiology and its control trough additives. Rev. Bras. Zootech. 39, 183-191.

Pahlow G., Muck R.E., Driehuis F., Oude Elferink S.J.W.H., Spoelstra S.F. 2003. Microbiology of ensiling. Silage science and technology. Agron. Monogr. 42, 95-139. DOI:10.2134/agronmonogr42.c3.

Pahlow G., Weissbach F. 1999. New aspects of evaluation and application of silage additives, in: Proceeding International Symposium. Contributions of grassland and forage research to the development of systems of sustainable land use. Völkenrode SH, Landbauforsch 206, 141-158.

PN-EN ISO 6887-1 : 2000. Microbiology of food and animal feeding stuffs. Preparation of test samples, initial suspension and decimal dilutions for microbiological examination.

PN-ISO 21527-1 : 2009. Mikrobiologia żywności i pasz. Horyzontalna metoda oznaczania liczby drożdży i pleśni. Cz. 1. Metoda liczenia kolonii w produktach o aktywności wody wyższej niż 0,95. [in Polish]

Potkański A., Grajewski J., Twarużek M., Selwet M., Miklaszewska B., Błajet-Kosicka A., Szumacher-Strabel, Cieślak A., Raczkowska-Werwińska K. 2010. Chemical composition, fungal microflora and mycotoxin content in maize silages infected by smut (Ustilago maydis) and the effect of biological and chemical additives on silage aerobic stability. J. Anim. Feed Sci. 19, 130-142.

Regulation (EC) No. 183/2005 of the European Parliament and of the Council of 12 January 2005 laying down requirements for feed hygiene, http://eur-lex.europa.eu/legal-content/EN/TXT/PDF/ /?uri=CELEX:32005R0183\&from=EN, access: 18.06.2017. 
Rossi F., Dellaglio F. 2007. Quality of silages from Italian farms as attested by number and identity of microbial indicators. J. Appl. Microbiol. 103, 1707-1715.

Wagner W., Wolf H., Losand B. 2007. Die Beurteilung des mikrobiologischen Status von Silagen. Übers. Tierernährg. 35, 93-102.

Wiedner G. 2009. Hygienestatus des Grundfutters - Erfahrungen eines Praxislabors. 15. Alpenländisches Expertenforum. Grundfutterqualität - aktuelle Ergebnisse und zukünftige Entwicklungen. LFZ Raumberg-Gumpenstein 27 März 2009, Raumberg-Gumpenstein, Landwirtschaft Zentrum für Bildung und Forschung im ländlichen Raum, 45-48.

\begin{abstract}
The number of fungi (yeasts and moulds) in silages is the determinant of their hygienic quality. The research material was green forage from a mixture of legumes and grasses and whole crop maize. The study was conducted in 2012-2014. Each year, green forages of a 2nd swath of a legume-grasses mixture being in 3-year field crop were ensiled. The green forages from maize of the same hybrid, cultivated according to the principles of crop rotation, were ensiled in wax stage. Chopped green forages was compacted and ensiled in minisilos with a capacity of $8654 \mathrm{~cm}^{3}$, which were opened after 6 weeks. In order to determine the number of moulds and yeasts in green forages and silages, mycological analysis was performed in accordance with PN-ISO 21527-1 : 2009. The mycological status of ensilaged green forages was bad. The number of moulds of the green forages of the legume-grasses mixtures was from 5.4225 (3rd year) to $5.4472 \mathrm{lg} \mathrm{cfu} \cdot \mathrm{g}^{-1}$ (1 st year), and yeast was at level from 4.9977 (3rd year) to $5.5792 \mathrm{lg} \mathrm{cfu} \cdot \mathrm{g}^{-1}$ (1st year). Moulds in whole crop maize occurred in the number of 4.6514 (1st year) to $6.4928 \mathrm{lg} \mathrm{cfu} \cdot \mathrm{g}^{-1}$ (2nd year), while yeast from 6.6710 (2nd year) to $7.2657 \mathrm{lg} \mathrm{cfu} \cdot \mathrm{g}^{-1}$ (1st year). Silages had significantly $(P \leq 0.001)$ less fungus than in green fodders. The hygienic quality of silages from the legume-grass mixtures was good in each year of the study. The number of mould and yeast did not exceed $3 \mathrm{lg} \mathrm{cfu} \cdot \mathrm{g}^{-1}$. Silages from whole crop maize had bad hygienic quality. Only in the silage of the 3rd year of the study, the presence of mould at a level of 1.7940 was noted, but yeast amounted to $6.2810 \mathrm{lg} \mathrm{cfu} \cdot \mathrm{g}^{-1}$.
\end{abstract}


